\title{
PERDAMAIAN DALAM KEBERAGAMAN DITINJAU DARI PERSPEKTIF AL- QUR'AN DAN BIBLE
}

\author{
Zunly Nadia \\ Sekolah Tinggi Agama Islam Sunan Pandanaran (STAISPA) Yogyakarta \\ Jl. Laksda Adisucipto, Caturtunggal, Kec. Depok, Kabupaten Sleman, \\ Daerah Istimewa Yogyakarta 55281 \\ e-mail: zunlynadia@yahoo.com
}

\begin{abstract}
Peace is one of the main teachings in Islam. As a boly book, the Qur'an and the Bible, the guidelines for its adherents to always love the peace. In both scriptures contains many verses that tell people to continue to realize peace on earth. Nevertheless it can not be denied that in both books also revealed verses about war. In this paper the author seeks to explain how the concept of peace in the perspective of the Qur'an and the Bible. The author only describes the concept of peace in the Qur'an as a boly book for Muslims and the Bible as the guidebook of Christians. This article concludes that to achieve that peace, there must be an awareness of religious plurality by respecting the existence of another religion which is of great importance in the religious context in Indonesia which is composed of various religions.
\end{abstract}

Keywords: peace, keberagaman Qur'an, Bible

\begin{abstract}
Abstrak
Perdamaian merupakan salah satu ajaran pokok dalam ajaran Islam. Sebagai sebuah kitab suci, al-Qur'an dan Bible, menjadi pedoman bagi pemeluknya untuk selalu cinta akan kedamaian. Dalam kedua kitab suci tersebut memuat banyak sekali ayat-ayat yang menyuruh umatnya untuk terus merealisasikan perdamaian di muka bumi. Meskipun demikian tidak dapat dipungkiri bahwa dalam kedua kitab tersebut juga diungkapkan ayat-ayat tentang peperangan. Dalam tulisan ini penulis berusaha akan menjelaskan bagaimana konsep perdamaian dalam perspektif al-Qur'an dan Bible. Penulis hanya memaparkan konsepperdamaian dalam al-Qur'an sebagai kitab suci bagi umat muslim dan bible sebagai kitab pedoman umat kristiani. Artikel ini menyimpulkan bahwa untuk mencapai perdamaian itu, harus ada kesadaran akan pluralitas agama dengan menghargai keberadaan agama lain yang merupakan hal yang sangat penting dalam konteks keberagamaan di Indonesia yang terdiri dari beragam agama.
\end{abstract}

Kata kunci: perdamaian, diversity, Al-Qur'an, Bible 


\section{Pendahuluan}

Sejarah memang banyak mencatat berbagai macam konflik dan perang di kalangan umat manusia, baik konflik antar suku, negara maupun konflik atas nama agama. Berapa banyak nyawa melayang dan dikorbankan karena tujuan-tujuan yang tidak semestinya. Dalam konflik atas nama agama misalnya, tercatat sebuah perang besar yang disebut dengan "the holy war" atau seringkali dikenal dengan perang salib yang masih meninggalkan trauma bagi sebagian besar pengikut agama baik Islam maupun Kristen hingga saat ini. Selain itu berapa banyak kekerasan yang terjadi di berbagai belahan dunia yang juga melibatkan nama agama secara tidak langsung, seperti kekerasan yang terjadi di Bosnia, Palestina, Irlandia, hingga Irak dan Syuriah yang membuat ada jarak dan sekat yang cukup lebar antar pemeluk agama, sehingga konsepsi terhadap pemeluk agama lain seringkali dipenuhi dengan berbagai kecurigaan yang pada akhirnya membangunkan kembali konflik atas nama agama.

Kenyataan ini membuat berbagai kalangan mempertanyakan kembali konsep perdamaian yang ada dalam setiap agama. Karena pada dasarnya kelahiran agama di muka bumi ini adalah untuk membuat kedamaian, keteraturan serta menyelesaikan persoalan-persoalan kemanusiaan dan bukannya justru membuat sekat dan konflik antar sesama manusia. Perdamaian merupakan sebuah keniscayaan bagi umat manusia yang ada di bumi. Tanpa adanya perdamaian tidak akan mungkin tercipta kehidupan yang harmonis.

Sebagai sebuah kitab suci, al-Qur'an dan Bible, menjadi pedoman bagi pemeluknya untuk selalu cinta akan kedamaian. Dalam kedua kitab suci tersebut memuat banyak sekali ayat-ayat yang menyuruh umatnya untuk terus merealisasikan perdamaian di muka bumi. Meskipun demikian tidak dapat dipungkiri bahwa dalam kedua kitab tersebut juga diungkapkan ayat-ayat tentang peperangan. Persoalan penafsiran terhadap teks- teks keagamaan inilah kemudian yang menjadikan perdamaian seolah menjadi sesuatu yang sulit untuk dijangkau oleh kedua pemeluk agama. Sehingga kedua pemeluk agama sering terlibat dalam perseturuan yang seolah tidak pernah berakhir.

Dalam tulisan ini penulis berusaha akan menjelaskan bagaimana konsep perdamaian dalam perspektif al-Qur'an dan Bible. Sengaja penulis hanya memaparkan konsep perdamaian dalam al-Qur'an sebagai kitab suci bagi umat muslim dan bible sebagai kitab pedoman umat kristiani, karena pertama; kedua pemeluk agama ini samasama sering terlibat perseteruan atas nama agama, catatan sejarah perjalanan kedua agama ini telah membuktikan hal ini. Kedua; kedua pemeluk agama Abraham ini merupakan penganut mayoritas di dunia dan ketiga; data-data diantara kedua agama ini cukup banyak dan sangat mudah untuk diakses.

\section{Pembahasan}

\section{Perdamaian dalam Perspektif Al-Qur'an}

Perdamaian merupakan salah satu ajaran pokok dalam ajaran Islam. Perintah untuk selalu berdamai tidak hanya terdapat dalam ayat-ayat al-Qur'an tetapi juga dicotohkan dalam kehidupan Rosulullah Saw. Sebagaimana diketahui Muhammad adalah sosok yang sangat dikenal dengan kepribadian dan budi pekertinya yang baik. Ada banyak peristiwa bersejarah yang memperlihatkan pribadi Rasulullah sebagai seorang juru damai. Bahkan jauh sebelum beliau diangkat menjadi seorang Nabi. Banyak perjanjian-perjanjian yang dibuat oleh Muhammad selama menjalankan misi dakwahnya dimana hal tersebut bertujuan untuk menghindari konflik dan berupaya membangun perdamaian. Mulai dari perjanjian Hudaibiyah, piagam Madinah, Perjanjian dengan delegasi Najran dan masih banyak lagi.

Kata Islam sendiri juga diambil dari kata "salama" yang berarti selamat dan juga "silm dan salaam" (damai) yang secara jelas menegaskan bahwa karakter dasar dari ajaran Islam adalah menyebarkan 
perdamaian. Beberapa point penting tentang ajaran perdamaian dalam al-Qur'an, diantaranya adalah:

1. Ajaran tentang perdamaian, larangan perang dan berbuat kekerasan

Al-Qur'an secara jelas melarang perang dan berbuat kekerasan. Diantara ayat-ayat alQur'an yang mengajarkan larangan perang dan berbuat kekerasan adalah: Q.S Al-Maidah : $32^{1}$, Q.S Al-Nisa : $29^{2}$

2. Diperbolehkannya upaya untuk mempertahankan diri

Ayat al-Qur'an yang berbicara tentang upaya untuk mempertahankan diri, diantaranya adalah: Q.S Al-Hajj : $39(22)^{3}$

3. Cara mengakhiri konflik

Ayat-ayat al-Qur'an yang menjelaskan dengan hal ini adalah: Q.S Yunus : $25^{4}$, Q.S Al-Hujurat (49): 9, ${ }^{5}$ Q.S Al-Anfal : $61,{ }^{6}$ Q.S Mumtahanah: $7 .^{7}$

1 "Sesungguhnya pembalasan terhadap orang-orang yang memerangi Allah dan Rasul-Nya dan membuat kerusakan di muka bumi, hanyalah mereka dibunuh atau disalib, atau dipotong tangan dan kaki mereka dengan bertimbal balik, atau dibuang dari negeri (tempat kediamannya). Yang demikian itu (sebagai) suatu penghinaan untuk mereka di dunia, dan di akhirat mereka beroleh siksaan yang besar."

2 "Dan barangsiapa berbuat demikian dengan melanggar hak dan aniaya, maka Kami kelak akan memasukkannya ke dalam neraka. Yang demikian itu adalah mudah bagi Allah"

3 (Yaitu) orang-orang yang telah diusir dari kampung halaman mereka tanpa alasan yang benar, kecuali karena mereka berkata:"Tuhan kami hanyalah Allah “. Dan sekiranya Allah tiada menolak (keganasan) sebagian manusia dengan sebagian yang lain, tentulah telah dirobohkan biara-biara Nasrani, gereja-gereja, rumah-rumah ibadat orang Yahudi dan masjid-masjid, yang di dalamnya banyak disebut nama Allah. Sesungguhnya Allah pasti menolong orang yang menolong (agama)Nya. Sesungguhnya Allah benar-benar Maha Kuat lagi Maha Perkasa.

${ }^{4}$ Bagi orang-orang yang berbuat baik, ada pahala yang terbaik (surga) dan tambahannya. Dan muka mereka tidak ditutupi debu hitam dan tidak (pula) kehinaan. Mereka itulah penghuni surga, mereka kekal di dalamnya.

${ }^{5}$ Sesungguhnya orang-orang mukmin adalah bersaudara karena itu damaikanlah antara kedua saudaramu dan bertaqwalah kepada Allah supaya kamu mendapat rahmat.

${ }^{6}$ Dan jika mereka bermaksud hendak menipumu, maka sesungguhnya cukuplah Allah (menjadi pelindungmu). Dialah yang memperkuatmu dengan pertolongan-Nya dan dengan para mukmin.

${ }^{7}$ Allah tiada melarang kamu untuk berbuat baik dan berlaku adil terhadap orang-orang yang tiada memerangimu karena agama dan tidak (pula) mengusir kamu dari negerimu. Sesungguhnya Allah menyukai orang-orang yang berlaku adil.
4. Pemberian maaf dan rekonsiliasi

Terkait dengan hal ini, Al-Qur'an menjelaskan dalam beberapa ayat, yakni: Q.S Yunus: $107,{ }^{8}$ Q.S Ali Imron 3: $103,{ }^{9}$ Q.S al-Baqarah : $263 .{ }^{10}$

5. Tuhan sang Maha adil

Ayat-ayat yang berbicara tentang hal ini, yakni: QS An-Nisa: 40, ${ }^{11}$ Q.S $6: 160,{ }^{12}$

6. Keadilan

Ayat-ayat al-Qur'an yang menjelaskan tentang hal ini, yaitu: Q.S Al-An'am : 151, ${ }^{13}$ QS AlMaidah:9, ${ }^{14}$ Q.S Annisa : $135,{ }^{15}$

\section{Rahmat}

${ }^{8}$ Katakanlah:" Wahai manusia, sesungguhnya telah datang kepadamu kebenaran (Al Qur'an) dari Tuhanmu, sebab itu barangsiapa yang mendapat petunjuk maka sesungguhnya (petunjuk itu) untuk kebaikan dirinya sendiri. Dan barangsiapa yang sesat, maka sesungguhnya kesesatannya itu untuk kecelakaan dirinya sendiri. Dan aku bukanlah seorang penjaga terhadap dirimu “.

${ }^{9}$ Dan janganlah kamu menyerupai orang yang bercerai berai dan berselisih sesudah datang keterangan yang jelas kepada mereka. Mereka itulah orang-orang yang mendapat siksa yang berat.

${ }^{10}$ Wahai orang-orang beriman, janganlah kamu menghilangkan (pahala) sedekahmu dengan menyebut-nyebutnya dan menyakiti (perasaan si penerima), seperti orang yang menafkahkan hartanya karena riya kepada manusia dan dia tidak beriman kepada Allah dan hari kemudian. Maka perumpamaan orang itu seperti batu licin yang di atasnya ada tanah, kemudian batu itu ditimpa hujan lebat, lalu menjadilah dia bersih (tidak bertanah). Mereka tidak menguasai sesuatupun dari apa yang mereka usahakan; dan Allah tidak memberi petunjuk kepada orang-orang yang kafir.

${ }^{11}$ Maka bagaimanakah (halnya orang kafir nanti), apabila Kami mendatangkan seseorang saksi (Rasul) dari tiap-tiap umat dan Kami mendatangkan kamu (Muhammad) sebagai saksi atas mereka itu (sebagai umatmu).

${ }^{12}$ Katakanlah:" Sesungguhnya aku telah ditunjuki oleh Tuhanku kepada jalan yang lurus, (yaitu) agama yang benar; agama Ibrahim yang lurus; dan Ibrahim itu bukanlah termasuk orangorang yang musyrik “.

${ }^{13}$ Dan janganlah kamu dekati harta anak yatim, kecuali dengan cara yang lebih bermanfaat, sehingga sampai ia dewasa. Dan sempurnakanlah takaran dan timbangan dengan adil. Kami tidak memikulkan beban kepada seseorang melainkan sekedar kesanggupannya. Dan apabila kamu berkata, maka hendaklah kamu berlaku adil kendatipun dia adalah kerabat (mu), dan penuhilah janji Allah. Yang demikian itu diperintahkan Allah kepadamu agar kamu ingat.

${ }^{14}$ Adapun orang-orang yang kafir dan mendustakan ayat-ayat Kami, mereka itu adalah penghuni neraka.

${ }^{15}$ Wahai orang-orang yang beriman, tetaplah beriman kepada Allah dan Rasul-Nya dan kepada kitab yang Allah turunkan kepada Rasul-Nya, serta kitab yang Allah turunkan sebelumnya. Barangsiapa yang kafir kepada Allah, malaikat-malaikat-Nya, kitab-kitab-Nya, Rasul-rasul-Nya, dan hari kemudian, maka sesungguhnya orang itu telah sesat sejauh-jauhnya. 
Terkait dengan rahmat, di dalam al-Qur'an banyak disebutkan, yakni kalimat bismillabialrahman al-rabim pada setiap awal surat, yang artinya adalah " Dengan Nama Allah yang Maha pengasih lagi maha penyayang". Ayatayat lain yang menjelaskan tentang rahmat, yaitu: QS Al-Baqarah : 218, ${ }^{16}$ Q.S Al-Baqarah : 83, ${ }^{17}$ Q.S Al-An'am : $54 .{ }^{18}$

8. Cara menunjukkan Kasih sayang

Dalam hal ini, dijelaskan dalam al-Qur'an, yakni: Q.S Al-insan: 8-9, ${ }^{19}$ QS. Al-isra: 26,28, ${ }^{20}$ QS. Al-Baqarah : $271,{ }^{21}$ Q.S An-Nur: $22 .{ }^{22}$

16 Sesungguhnya orang-orang yang beriman, orangorang yang berhijrah dan berjihad di jalan Allah, mereka itu mengharapkan rahmat Allah, dan Allah Maha Pengampun lagi Maha Penyayang.

${ }^{17}$ Dan (ingatlah), ketika Kami mengambil janji dari Bani Israil (yaitu): Janganlah kamu menyembah selain Allah, dan berbuat kebaikanlah kepada ibu bapa, kaum kerabat, anak-anak yatim, dan orang-orang miskin, serta ucapkanlah kata-kata yang baik kepada manusia, dirikanlah shalat dan tunaikanlah zakat. Kemudian kamu tidak memenuhi janji itu, kecuali sebahagian kecil daripada kamu, dan kamu selalu berpaling

${ }^{18}$ Apabila orang-orang yang beriman kepada ayat-ayat Kami itu datang kepadamu, maka katakanlah: "Salaamun alaikum [476]. Tuhanmu telah menetapkan atas diri-Nya kasih sayang [477], (yaitu) bahwasanya barang siapa yang berbuat kejahatan di antara kamu lantaran kejahilan [478], kemudian ia bertaubat setelah mengerjakannya dan mengadakan perbaikan, maka sesungguhnya Allah Maha Pengampun lagi Maha Penyayang.

${ }^{19}$ Dan mereka memberikan makanan yang disukainya kepada orang miskin, anak yatim dan orang yang ditawan.(9) Sesungguhnya kami memberi makanan kepadamu hanyalah untuk mengharapkan keridhaan Allah, kami tidak menghendaki balasan dari kamu dan tidak pula (ucapan) terima kasih.

${ }^{20}(26)$ Dan berikanlah kepada keluarga-keluarga yang dekat akan haknya, kepada orang miskin dan orang yang dalam perjalanan dan janganlah kamu menghambur-hamburkan (hartamu) secara boros.(28) Dan jika kamu berpaling dari mereka untuk memperoleh rahmat dari Tuhanmu yang kamu harapkan, maka katakanlah kepada mereka ucapan yang pantas

${ }^{21}$ Jika kamu menampakkan sedekah(mu), maka itu adalah baik sekali. Dan jika kamu menyembunyikannya dan kamu berikan kepada orang-orang fakir, maka menyembunyikan itu lebih baik bagimu. Dan Allah akan menghapuskan dari kamu sebagian kesalahan-kesalahanmu; dan Allah mengetahui apa yang kamu kerjakan

${ }^{22}$ Dan janganlah orang-orang yang mempunyai kelebihan dan kelapangan di antara kamu bersumpah bahwa mereka (tidak) akan memberi (bantuan) kepada kaum kerabat(nya), orang-orang yang miskin dan orang-orang yang berhijrah pada jalan Allah, dan hendaklah mereka mema'afkan dan berlapang dada. Apakah kamu tidak ingin bahwa Allah mengampunimu? Dan Allah adalah Maha Pengampun lagi Maha Penyayang
9. Ajaran tentang toleransi dan saling menghargai Ayat-ayat yang berbicara tentang toleransi dan saling menghargai, diantaranya adalah: Q.S al-Hujurat:13, ${ }^{23}$ Q.S Luqman: $18,{ }^{24} \mathrm{Q} . \mathrm{S}$ al-Furqan: $63,{ }^{25}$ Q.S Al-Hujurat: $11,{ }^{26}$ Q.S AlQashash: $55,{ }^{27}$ Q.S Al-Imron : $159,{ }^{28}$

10. Kebebasan beragama dan dialog antar agama Ayat-ayat yang berbicara tentang kebebasan beragama dan dialog antar agama, diantaranya adalah: Q.S Al-Baqarah : $256,{ }^{29}$ Q.S Yunus: $99-100,{ }^{30}$

${ }^{23} \mathrm{Hai}$ manusia, sesungguhnya Kami menciptakan kamu dari seorang laki-laki dan seorang perempuan dan menjadikan kamu berbangsa-bangsa dan bersuku-suku supaya kamu saling kenal-mengenal. Sesungguhnya orang yang paling mulia di antara kamu di sisi Allah ialah orang yang paling taqwa di antara kamu. Sesungguhnya Allah Maha Mengetahui lagi Maha Mengenal.

${ }^{24}$ Dan janganlah kamu memalingkan mukamu dari manusia (karena sombong) dan janganlah kamu berjalan di muka bumi dengan angkuh. Sesungguhnya Allah tidak menyukai orang-orang yang sombong lagi membanggakan diri.

${ }^{25}$ Dan hamba-hamba Tuhan yang Maha Penyayang itu (ialah) orang-orang yang berjalan di atas bumi dengan rendah hati dan apabila orang-orang jahil menyapa mereka, mereka mengucapkan kata-kata (yang mengandung) keselamatan.

${ }^{26} \mathrm{Hai}$ orang-orang yang beriman, janganlah sekumpulan orang laki-laki merendahkan kumpulan yang lain, boleh jadi yang ditertawakan itu lebih baik dari mereka. Dan jangan pula sekumpulan perempuan merendahkan kumpulan lainnya, boleh jadi yang direndahkan itu lebih baik. Dan janganlah suka mencela dirimu sendiri dan jangan memanggil dengan gelaran yang mengandung ejekan. Seburuk-buruk panggilan adalah (panggilan) yang buruk sesudah iman dan barangsiapa yang tidak bertobat, maka mereka itulah orang-orang yang zalim.

${ }^{27}$ Dan apabila mereka mendengar perkataan yang tidak bermanfaat, mereka berpaling daripadanya dan mereka berkata: "Bagi kami amal-amal kami dan bagimu amal-amalmu, kesejahteraan atas dirimu, kami tidak ingin bergaul dengan orangorang jahil”.

${ }^{28}$ Maka disebabkan rahmat dari Allah-lah kamu berlaku lemah lembut terhadap mereka. Sekiranya kamu bersikap keras lagi berhati kasar, tentulah mereka menjauhkan diri dari sekelilingmu. Karena itu ma'afkanlah mereka, mohonkanlah ampun bagi mereka, dan bermusyawaratlah dengan mereka dalam urusan itu . Kemudian apabila kamu telah membulatkan tekad, maka bertawakkallah kepada Allah. Sesungguhnya Allah menyukai orang-orang yang bertawakkal kepada-Nya.

29 "Tidak ada paksaan utk agama itu . Sesungguhnya telah jelas jalan yg benar daripada jalan yg sesat.."

${ }^{30}$ (99)Dan jikalau Tuhanmu menghendaki, tentulah beriman semua orang yang di muka bumi seluruhnya. Maka apakah kamu (hendak) memaksa manusia supaya mereka menjadi orang-orang yang beriman semuanya ?(100) Dan tidak ada seorangpun akan beriman kecuali dengan izin Allah; dan Allah menimpakan kemurkaan kepada orang-orang yang tidak mempergunakan akalnya. 
11. Muslim, Kristen dan Yahudi

A1-Qur'an sebagai kitab suci bagi umat Islam juga berbicara tentang agama yang hadir sebelum Islam, yakni Kristen dan Yahudi, yang dijelaskan dalam beberapa ayat, yaitu: Q.S A1Maaidah : $14,{ }^{31}$ Q.S Al-Maidah: $82-83,{ }^{32}$ Q.S Al-Ankabut: 46,33

\section{Hubungan Antar Agama}

Ayat-ayat al-Qur'an yang berbicara tentang hubungan antar agama, adalah: Q.S Alkafirun:1-6, ${ }^{34}$ Q.S Az-Zukhruf: 88-89.35

13. Dialog antar agama

Dialog antar agama juga menjadi salah satu konsep yang dibicarakan oleh al-Qur'an, yang

${ }^{31}$ Dan diantara orang-orang yang mengatakan: "Sesungguhnya kami ini orang-orang Nasrani", ada yang telah kami ambil perjanjian mereka, tetapi mereka (sengaja) melupakan sebagian dari apa yang mereka telah diberi peringatan dengannya; maka Kami timbulkan di antara mereka permusuhan dan kebencian sampai hari kiamat. Dan kelak Allah akan memberitakan kepada mereka apa yang mereka kerjakan.

${ }^{32}$ (82)Sesungguhnya kamu dapati orang-orang yang paling keras permusuhannya terhadap orang-orang yang beriman ialah orang-orang Yahudi dan orang-orang musyrik. Dan sesungguhnya kamu dapati yang paling dekat persahabatannya dengan orangorang yang beriman ialah orang-orang yang berkata: "Sesungguhnya kami ini orang Nasrani". Yang demikian itu disebabkan karena di antara mereka itu (orang-orang Nasrani) terdapat pendetapendeta dan rahib-rahib, (juga) karena sesungguhnya mereka tidak menymbongkan diri.

(83)Dan apabila mereka mendengarkan apa yang diturunkan kepada Rasul (Muhammad), kamu lihat mata mereka mencucurkan air mata disebabkan kebenaran (Al-Qur'an) yang telah mereka ketahui (dari kitab-kitab mereka sendiri); seraya berkata: "Ya Tuhan kami, kami telah beriman, maka catatlah kami bersama orangorang yang menjadi saksi (atas kebenaran Al-Qur'an dan kenabian Muhammad SAW).

${ }^{33}$ Dan janganlah kamu berdebat denganAhli Kitab, melainkan dengan cara yang paling baik, kecuali dengan orang-orang zalim di antara mereka, dan katakanlah: "Kami telah beriman kepada (kitab-kitab) yang diturunkan kepada kami dan yang diturunkan kepadamu; Tuhan kami dan Tuhanmu adalah satu; dan kami hanya kepada-Nya berserah diri".

${ }^{34}$ 1. Katakanlah: "Hai orang-orang kafir, 2. Aku tidak akan menyembah apa yang kamu sembah. 3. Dan kamu bukan penyembah Tuhan yang aku sembah. 4. Dan aku tidak pernah menjadi penyembah apa yang kamu sembah, 5. dan kamu tidak pernah (pula) menjadi penyembah Tuhan yang aku sembah. 6 . Untukmu agamamu, dan untukkulah, agamaku”.

${ }^{35}$ 88. dan (Allah mengetabui) ucapan Muhammad: "Ya Tuhanku, sesungguhnya mereka itu adalah kaum yang tidak beriman". 89. Maka berpalinglah (hai Muhammad) dari mereka dan katakanlah: "Salam (selamat tinggal)." Kelak mereka akan mengetahui (nasib mereka yang buruk). terdapat dalam ayat-ayat diantaranya adalah Q.S An-Nahl: $125,{ }^{36}$ Q.S Ibrahim: $24 .{ }^{37}$

Dalam ungkapan teks agama, perdamaian sering dibahaskan dengan al-aman, secara terminologi al-amān, adalah sebuah kesepakatan untuk menghentikan peperangan dan pembunuhan dengan pihak musuh. Selain al-aman, masih ada beberapa istilah lain yang juga merujuk pada perdamaian yakni al-sulh, al-hudnah, al-mu'ahadah dan aqd al-zimmah. Ayat-ayat diatas adalah ayatayat yang menunjukkan ajaran perdamaian. Meski banyak diantara ayat-ayat diatas tidak secara eksplisit menyatakan perintah perdamaian akan tetapi secara tersirat ayat tersebut mengajak umat muslim untuk membuat perdamaian. Misalnya ayatayat tentang berbuat adil, larangan untuk berbuat kekerasan $^{38}$, serta ayat-ayat tentang hubungan antar agama $^{39}$ serta universalitas agama.

Melihat teks-teks yang ada dalam al-Qur'an tersebut, maka akan terlihat wajah Islam yang damai dan menjadi penebar kedamaian. Dalam ayat tentang universalitas agama misalnya, terlihat bahwasanya Islam mengakui adanya pluralitas ${ }^{40}$. Islam juga mengajarkan umatnya untuk tidak memaksakan kehendak dalam beragama ${ }^{41}$. Bahkan Islam juga mengajarkan bagaimana cara berhubungan dengan pemeluk agama lain. Ungkapan salam yang selalu diucapkan oleh kaum muslimin tidak hanya sekedar ucapan salam tetapi lebih dari itu, yakni merupakan perintah untuk selalu menebarkan perdamaian dimanapun berada. Namun demikian

${ }^{36} 125$. Serulah (manusia) kepada jalan Tuhan-mu dengan hikmah [845] dan pelajaran yang baik dan bantahlah mereka dengan cara yang baik. Sesungguhnya Tuhanmu Dialah yang lebih mengetahui tentang siapa yang tersesat dari jalan-Nya dan Dialah yang lebih mengetahui orang-orang yang mendapat petunjuk.

${ }^{37}$ Tidakkah kamu perhatikan bagaimana Allah telah membuat perumpamaan kalimat yang baik [786] seperti pohon yang baik, akarnya teguh dan cabangnya (menjulang) ke langit, [786] Termasuk dalam "kalimat yang baik" ialah kalimat tauhid, segala ucapan yang menyeru kepada kebajikan dan mencegah dari kemungkaran serta perbuatan yang baik. Kalimat tauhid seperti "laa ilaa ha illallaah".

${ }^{38} \mathrm{QS}$ Adz-Dzariyat [51]: 56

${ }^{39} \mathrm{QS}$ Al-Kafirun 1-6

${ }^{40} \mathrm{QS}$ al-Hujurat [49]: 13

${ }^{41}$ QS Al-Baqarah 256 
dalam tataran praktis wajah damai Islam yang merupakan salah ajaran yang paling penting dalam agama Islam ini sering dinodai oleh praktik-praktik kekerasan dan pemaksaan oleh beberapa oknum dengan mengatasnamakan agama dan dengan dalih amar ma'ruf nabi mungkar. Sebuah konsep dakwah yang diwajibkan bagi setiap umat muslim. Prilaku-prilaku demikian ini membuat wajah Islam dinodai dan dipersepsikan sebagai agama kekerasan. Sebagaimana yang ditulis oleh Max Weber bahwa Islam adalah agama yang memiliki etos keprajuritan, tetapi tidak memiliki etos kewiraswastaan. ${ }^{42}$ Penyebaran Islam bahkan sering difahami dengan gambaran seseorang yang "memegang al-Quran di tangan kanan dan pedang di tangan kirinya". Pendapat Max Weber ini memang tidak "sepenuhnya salah" ketika melihat prilaku radikalisme agama di kalangan kaum muslimin sehingga berwujud pada munculnya kekerasan serta pemaksaan dalam beragama. Namun pendapat ini jelas merupakan pendapat yang sangat tidak diterima ketika melihat secara menyeluruh ajaran Islam serta ayat-ayat yang terdapat dalam al-Qur'an. Artinya jelas bukan ajaran Islam yang memiliki etos keprajuritan karena sesungguhnya Islam adalah agama perdamaian.

Dalam mengajarkan perdamaian, ayatayat di dalam al-Qur'an tidak banyak menyebut kata perdamaian secara eksplisit, akan tetapi banyak sekali ayat-ayat yang mengajarkan untuk senantiasa berbuat baik dan menekankan adanya keseimbangan antara hubungan vertikal dengan Tuhan dan hubungan horizontal dengan sesama manusia dimana jika ajaran-ajaran ini dilakukan dengan baik tentu saja akan berimplikasi pada perdamaian di dunia. Perintah atau anjuran berbuat baik kepada sesama adalah modal awal membangun perdamaian. Perbuatan baik kepada sesama adalah pintu utama dalam mewujudkan perdamaian. Perdamaian tidak akan tercipta dengan kezaliman karena akan selalu muncul perlawanan dari orang

${ }^{42}$ Stabislav Andreski, Max Weber: Kapitalisme, Birokrasi dan Agama, terj. Hartono H, (Yogyakarta: Tiara Wacana, 1996), hlm 121. yang dizalimi. Ibarat kata pepatah, semut pun akan marah jika diinjak. Oleh karena itu, perintah Islam kepada umatnya agar beramal saleh merupakan fondasi bagi terwujudnya perdamaian dunia.

Dalam perintah dalam shalat misalnya, sebagai bentuk ibadah tertinggi dalam Islam. Shalat dimulai dengan takbir, yaitu menjunjung tinggi Asma Allah menhunjam erat ke dalam jiwa sang pelaku. Maka shalat adalah bentuk dzikir (mengingat Allah) tertinggi, yang dengannya seorang Muslim merasakan kedamaian bathin yang tak terhingga. Namun kedamaian jiwa tidak berakhir, tetapi harus diteruskan dengan kedamaian yang lebih luas, yaitu kedamaian sosial. Untuk itu, shalat tak akan menjadi valid ketika tidak diakhiri dengan komitmen menyebarkan perdamaian kepada sesama. Salam yang diucapkan di akhir shalat adalah bentuk komitmen tertinggi dari seorang Muslim dalam mewujudkan perdamaian sosial.

Demikianlah konsep damai yang ada dalam al-Qur'an. Semua ajaran, perintah yang ada dalam ajaran Islam sebenarnya berujung pada terciptanya perdamaian dan keadilan di dunia. Kedatangan Islam di tengah bangsa arab yang pada masa itu jelas mempunyai misi perdamaian. Bangsa Arab yang saat itu terpecah belah kedalam suku-suku dan suka berperang menjadi sebuah satu komunitas dibawah konsep keumatan. Sehingga semua manusia disamakan kedudukannya kecuali atas dasar iman. Disinilah kemudian kedatangan Islam membawa pergeseran yang cukup fundamental dalam system sosial bangsa Arab dari yang awalnya terpusat pada pertalian atas dasar kekeluargaan menjadi pertalian atas dasar keimanan dibawah konsep ummat ${ }^{43}$.

Muhammad Abduh dalam al-Islam wa alNashraniyyah: bayn al-'Ilm wa al-Madaniyyah juga menulis bahwa ajaran perdamaian Islam mewujud dalam struktur kekuasaan. Sebab dalam sejarah kekuasaan Islam, utamanya pada dinasti Umayyah

${ }^{43}$ Harold Coward and Gordon S Smith (ed.), Religion and Peacebuilding, (USA : State University of NewYork, 2004), hlm 130-131. 
dan Abbasiyah, ditemukan sejumlah orang-orang Yahudi dan Kristen yang menjadi bendahara, sekretaris, tim dokter, bahkan penasehat raja. Ini tidak lain disemangati, bahwa dalam sistem kekuasaan sekalipun, perdamaian harus diutamakan, karena hampir tidak mungkin membangun tatanan masyarakat yang maju, adil, dan sejahtera tanpa basis perdamaian yang kuat ${ }^{44}$. Ini merupakan fakta sejarah Islam bagaimana sikap tasāmuh (toleran) dan kasih sayang kaum muslimin terhadap pemeluk agama lain, baik yang tergolong ke dalam abl al-Kitab maupun kaum musyrik, bahkan terhadap seluruh makhluk, Islam mendahulukan sikap kasih sayang, keharmonisan dan dan kedamaian ${ }^{45}$.

\section{Perdamaian dalam Perspektif Bible}

Pesan damai sangat terasa bagi umat kristiani, Yesus sebagai tokoh sentral dalam agama Kristen senantiasa mengajarkan umatnya untuk cinta damai. Yesus tidak hanya dikenal sebagi juru selamat tetapi juga diberi gelar sebagai Raja damai karena Dia adalah seorang yang anti terhadap kekerasan. Banyak cerita yang menggambarkan betapa Yesus adalah sang juru damai, bahkan di dalam bible dapat dilihat baha tidak satupun ayat yang mengindikasikan bahwa Yesus pernah mengajak orang untuk berperang. Diantara ajaran Yesus tentang perdamaian adalah Yesus mengajarkan untuk melawan kekerasan tanpa kekerasan. Ajaran melawan kekerasan tanpa kekerasan ini bukan berarti mengajarkan kepasrahan atau tanpa perlawanan, tetapi juga mengajarkan jalan ketiga misalnya dengan menggunakan kekuatan moral daripada kekuatan fisik, mencari alternatif lain daripada menggunakan kekerasan, tidak membalas dendam, dan lain sebagainya ${ }^{46}$. Adapun ayat-ayat yang mengajarkan perdamaian dalam bible diantaranya adalah:

${ }^{44}$ Ian Suherlan, Menegakkan Perdamaian dan Keadilan, Buletin No.185,www.cmm.or.id/cmm-ind_more.php?id=A4473_0_3.

${ }^{45}$ Hermanto Harun, Islam dan Perdamaian dalam http:// ibnuharun.multiply.com/journal/item/12

${ }^{46}$ Muhaimin AG (ed.), Damai di dunia Damai untuk Semua Perspektifberbagai Agama, (Jakarta : Proyek Peningkatan Pengkajian Hidup Umat Beragama, Badan Litbang Agama dan Diklat Keagamaan, Departemen Agama RI, 2004), hlm 130-147
1. Perdamaian, larangan perang dan berbuat kekerasan

Dalam Bible disebutkan diantaranya dalam kitab keluaran 20:13 ${ }^{47}$

2. Mengakhiri Konflik

Dalam disebutkan diantaranya dalam Yesaya $14: 7,{ }^{48}$ Matius 5:9, ${ }^{49}$ Yesaya 2:4, ${ }^{50}$ Yesaya $32: 17.51$

3. Pemberian maaf dan rekonsiliasi

Beberapa ayat dalam bible yang berbicara tentang pemberian maaf dan rekonsiliasi diantaranya adalah: Daniel 9: 9,52 Yohanes 4:16, ${ }^{53}$ Imamat 19:17-18, ${ }^{54}$ Lukas $6: 27,{ }^{55}$ Matius 6: $12,{ }^{56}$ Matius $18: 21-22,{ }^{57}$ Matius 5:

\footnotetext{
${ }^{47}$ Jangan Membunuh

${ }^{48}$ (7) Segenap bumi sudah aman dan tenteram; orang bergembira dengan sorak-sorai.

${ }^{49}$ (9) Berbahagialah orang yang membawa damai, karena mereka akan disebut anak-anak Allah.

${ }^{50} \mathrm{Ia}$ akan menjadi hakim antara bangsa-bangsa dan akan
} menjadi wasit bagi banyak suku bangsa; maka mereka akan menempa pedang-pedangnya menjadi mata bajak dan tombaktombaknya menjadi pisau pemangkas; bangsa tidak akan lagi mengangkat pedang terhadap bangsa, dan mereka tidak akan lagi belajar perang.

${ }^{51} \mathrm{Di}$ mana ada kebenaran di situ akan tumbuh damai sejahtera, dan akibat kebenaran ialah ketenangan dan ketenteraman untuk selama-lamanya

${ }^{52}$ Di mana ada kebenaran di situ akan tumbuh damai sejahtera, dan akibat kebenaran ialah ketenangan dan ketenteraman untuk selama-lamanya

${ }^{53}$ Dalam hal inilah kasih Allah sempurna di dalam kita, yaitu kalau kita mempunyai keberanian percaya pada hari penghakiman, karena sama seperti Dia, kita juga ada di dalam dunia ini.

${ }^{54}$ (18) Janganlah engkau menuntut balas, dan janganlah menaruh dendam terhadap orang-orang sebangsamu, melainkan kasihilah sesamamu manusia seperti dirimu sendiri; Akulah TUHAN. (19) Kamu harus berpegang kepada ketetapan$\mathrm{Ku}$. Janganlah kawinkan dua jenis ternak dan janganlah taburi ladangmu dengan dua jenis benih, dan janganlah pakai pakaian yang dibuat dari pada dua jenis bahan.memberi petunjuk kepada orang-orang yang kafir.

${ }^{55}$ Tetapi kepada kamu, yang mendengarkan Aku, Aku berkata: Kasihilah musuhmu, berbuatlah baik kepada orang yang membenci kamu;

${ }^{56}$ (12) dan ampunilah kami akan kesalahan kami, seperti kami juga mengampuni orang yang bersalah kepada kami;

${ }^{57}$ (21) Kemudian datanglah Petrus dan berkata kepada Yesus: "Tuhan, sampai berapa kali aku harus mengampuni saudaraku jika ia berbuat dosa terhadap aku? Sampai tujuh kali?” (22) Yesus berkata kepadanya: "Bukan! Aku berkata kepadamu: Bukan sampai tujuh kali, melainkan sampai tujuh puluh kali tujuh kali. 
38-39, ${ }^{58}$ Lukas 6:35, ${ }^{59}$ Lukas 6:37. ${ }^{60}$

4. Tuhan Sang Maha Adil

Ayat-ayat dalam Bible yang berbicara tentang

Tuhan sebagai Dzat yang Maha Adil, adalah: Ulangan $32: 4,{ }^{61}$ Mazmur 116: 5-6, ${ }^{62}$

5. Keadilan

Ayat-ayat bible yang berbicara tentang keadilan diantaranya adalah: Mazmur 146:8, ${ }^{63}$ Amtsal $14: 34,{ }^{64}$ Amtsal 15: 6, ${ }^{65}$ Imamat 19: $15,{ }^{66}$ Matius 7:12, ${ }^{67}$ Samuel 26:23, ${ }^{68}$ Matius 5:6, ${ }^{69}$

6. Rahmat/Kasih sayang

Ayat-ayat tentang rahmat/kasih sayang diantaranya adalah: Lukas $6: 36,{ }^{70}$ Matius 5

${ }^{58}$ (38) Kamu telah mendengar firman: Mata ganti mata dan gigi ganti gigi. (39) Tetapi Aku berkata kepadamu: Janganlah kamu melawan orang yang berbuat jahat kepadamu, melainkan siapapun yang menampar pipi kananmu, berilah juga kepadanya pipi kirimu.

${ }^{59}$ (35) Tetapi kamu, kasihilah musuhmu dan berbuatlah baik kepada mereka dan pinjamkan dengan tidak mengharapkan balasan, maka upahmu akan besar dan kamu akan menjadi anakanak Allah Yang Mahatinggi, sebab Ia baik terhadap orang-orang yang tidak tahu berterima kasih dan terhadap orang-orang jahat.

${ }^{60}(37)$ Janganlah kamu menghakimi, maka kamupun tidak akan dihakimi. Dan janganlah kamu menghukum, maka kamupun tidak akan dihukum; ampunilah dan kamu akan diampuni.

${ }^{61}$ Gunung Batu, yang pekerjaan-Nya sempurna, karena segala jalan-Nya adil, Allah yang setia, dengan tiada kecurangan, adil dan benar Dia.

${ }^{62}(5)$ TUHAN adalah pengasih dan adil, Allah kita penyayang. 6) TUHAN memelihara orang-orang sederhana; aku sudah lemah, tetapi diselamatkan-Nya aku.

$\left.{ }^{63} 8\right)$ TUHAN membuka mata orang-orang buta, TUHAN menegakkan orang yang tertunduk, TUHAN mengasihi orangorang benar.

${ }^{64}(34)$ Kebenaran meninggikan derajat bangsa, tetapi dosa adalah noda bangsa.

${ }^{65} 6$ ) Di rumah orang benar ada banyak harta benda, tetapi penghasilan orang fasik membawa kerusakan.

${ }^{66}(15)$ Janganlah kamu berbuat curang dalam peradilan; janganlah engkau membela orang kecil dengan tidak sewajarnya dan janganlah engkau terpengaruh oleh orang-orang besar, tetapi engkau harus mengadili orang sesamamu dengan kebenaran.

${ }^{67}(12)$ Segala sesuatu yang kamu kehendaki supaya orang perbuat kepadamu, perbuatlah demikian juga kepada mereka. Itulah isi seluruh hukum Taurat dan kitab para nabi.

${ }^{68}(23)$ TUHAN akan membalas kebenaran dan kesetiaan setiap orang, sebab TUHAN menyerahkan engkau pada hari ini ke dalam tanganku, tetapi aku tidak mau menjamah orang yang diurapi TUHAN.

${ }^{69}(6)$ Berbahagialah orang yang lapar dan haus akan kebenaran, karena mereka akan dipuaskan.

${ }^{70}$ Hendaklah kamu murah hati, sama seperti Bapamu adalah murah hati."

\section{: 7, ${ }^{71}$ Ulangan $4: 31,{ }^{72} 1$ Korintus 13: $4-6,{ }^{73}$}

Amtsal 19:17, ${ }^{74}$ Mazmur 146: 1, 7-9, ${ }^{75}$

\section{Cara menunjukkan kasih sayang}

Terkait dengan hal ini, terdapat di dalam ayatayat, yang diantaranya adalah Galatia 5: 1314, ${ }^{76}$ Imamat $25: 35,{ }^{77}$ Keluaran $23: 9,{ }^{78}$ Imamat 19:33-34, ${ }^{79}$ Ayub 31:31-32, ${ }^{80}$ Matius 25: 35$36,40,{ }^{81}$

${ }^{71}$ Berbahagialah orang yang murah hatinya, karena mereka akan beroleh kemurahan.

${ }^{72}$ (31) Sebab TUHAN, Allahmu, adalah Allah Penyayang, Ia tidak akan meninggalkan atau memusnahkan engkau dan Ia tidak akan melupakan perjanjian yang diikrarkan-Nya dengan sumpah kepada nenek moyangmu.

${ }^{73}$ 4.Kasih itu sabar. Kasih tahu tidak iri atau cemburu. Cinta itu tidak maju dan self-tegas, tidak sombong dan sombong. 5. Dia tidak berperilaku unbecomingly, atau berusaha untuk memperluaskan dirinya sendiri, maupun kobaran api di kemarahan bergairah, atau merenung atas kesalahan. 6. Dia tidak menemukan kesenangan dalam ketidakadilan yang dilakukan kepada orang lain, tetapi dengan sukacita sisi dengan kebenaran.

${ }^{74}$ Siapa menaruh belas kasihan kepada orang yang lemah, memiutangi TUHAN, yang akan membalas perbuatannya itu.

${ }^{75}$ Haleluya! Pujilah TUHAN, hai jiwaku! (7) yang menegakkan keadilan untuk orang-orang yang diperas, yang memberi roti kepada orang-orang yang lapar. TUHAN membebaskan orangorang yang terkurung, (8) TUHAN membuka mata orang-orang buta, TUHAN menegakkan orang yang tertunduk, TUHAN mengasihi orang-orang benar. (9) TUHAN menjaga orang-orang asing, anak yatim dan janda ditegakkan-Nya kembali, tetapi jalan orang fasik dibengkokkan-Nya.

${ }^{76}$ 5:13 Sebab, saudara-saudara, kamu telah dipanggil kepada kebebasan, hanya [menggunakan] bukan kebebasan untuk sebuah kesempatan untuk daging, tetapi oleh kasih melayani satu sama lain. 5:14 Untuk semua hukum itu terpenuhi dalam satu kata, [bahkan] di ini; Kasihilah sesamamu manusia seperti dirimu sendiri.

${ }^{77}$ Apabila saudaramu jatuh miskin, sehingga tidak sanggup bertahan di antaramu, maka engkau harus menyokong dia sebagai orang asing dan pendatang, supaya ia dapat hidup di antaramu.

${ }^{78}$ Orang asing janganlah kamu tekan, karena kamu sendiri telah mengenal keadaan jiwa orang asing, sebab kamupun dahulu adalah orang asing di tanah Mesir.

${ }^{79}$ 19:33 Apabila seorang asing tinggal padamu di negerimu, janganlah kamu menindas dia. 19:34 Orang asing yang tinggal padamu harus sama bagimu seperti orang Israel asli dari antaramu, kasihilah dia seperti dirimu sendiri, karena kamu juga orang asing dahulu di tanah Mesir; Akulah TUHAN, Allahmu

${ }^{80} 31$ :31 Jikalau orang-orang di kemahku mengatakan: Siapa yang tidak kenyang dengan lauknya? 31:32 --malah orang asingpun tidak pernah bermalam di luar, pintuku kubuka bagi musafir!

${ }^{81}$ (35) Sebab ketika Aku lapar, kamu memberi Aku makan; ketika Aku haus, kamu memberi Aku minum; ketika Aku seorang asing, kamu memberi Aku tumpangan; (36) ketika Aku telanjang, kamu memberi Aku pakaian; ketika Aku sakit, kamu melawat Aku; ketika Aku di dalam penjara, kamu mengunjungi Aku. (40) Dan Raja itu akan menjawab mereka: Aku berkata kepadamu, sesungguhnya segala sesuatu yang kamu lakukan untuk salah 
8. Ajaran tentang toleransi dan saling menghargai Ayat-ayat yang berbicara tentang ajaran toleransi dan saling menghargai di dalam bible, diantaranya adalah: Amtsal 11:12, ${ }^{82}$ Amtsal $15: 4,{ }^{83}$ Lukas $6: 37,{ }^{84}$ Lukas $6: 41-42 .{ }^{85}$

9. Kebebasan beragama dan dialog antar agama Dalam hal ini terdapat Apokrifa, Sirakh 15:14. ${ }^{86}$

10. Dialog antar agama

Terkait dengan dialog antar agama terdapat dalam beberapa ayat, yakni:

Amtsal 16:20-21, ${ }^{87}$ Amtsal 15: $28,{ }^{88}$ Lukas 6 : $43-44,{ }^{89}$ Lukas $6: 45,{ }^{90}$

Ayat-ayat yang tersebut diatas sangat jelas tertulis bagaimana perdamaian juga menjadi tujuan utama dari ajaran Yesus. Bible berbicara tentang keadilan, pentingnya pemberian maaf serta mengasihi sekalipun terhadap musuh dan lain sebagainya. Yesus sebagai pembawa pesan damai juga

seorang dari saudara-Ku yang paling hina ini, kamu telah melakukannya untuk Aku.

${ }^{82}$ Siapa menghina sesamanya, tidak berakal budi, tetapi orang yang pandai, berdiam diri.

${ }^{83}$ Lidah lembut adalah pohon kehidupan, tetapi lidah curang melukai hati.

84“Janganlah kamu menghakimi, maka kamupun tidak akan dihakimi. Dan janganlah kamu menghukum, maka kamupun tidak akan dihukum; ampunilah dan kamu akan diampuni.

${ }^{85}$ 6:41Mengapakah engkau melihat selumbar di dalam mata saudaramu, sedangkan balok di dalam matamu sendiri tidak engkau ketahui?6:42Bagaimanakah engkau dapat berkata kepada saudaramu: Saudara, biarlah aku mengeluarkan selumbar yang ada di dalam matamu, padahal balok yang di dalam matamu tidak engkau lihat? Hai orang munafik, keluarkanlah dahulu balok dari matamu, maka engkau akan melihat dengan jelas untuk mengeluarkan selumbar itu dari mata saudaramu."

${ }^{86} \mathrm{Dia}$ sendiri membuat manusia dari awal, dan meninggalkannya di tangan nasihatnya;

${ }^{87}$ (20) Siapa memperhatikan firman akan mendapat kebaikan, dan berbahagialah orang yang percaya kepada TUHAN. (21) Orang yang bijak hati disebut berpengertian, dan berbicara manis lebih dapat meyakinkan.

88 (28) Hati orang benar menimbang-nimbang jawabannya, tetapi mulut orang fasik mencurahkan hal-hal yang jahat.

$\left.{ }^{89} 43\right)$ Karena tidak ada pohon yang baik yang menghasilkan buah yang tidak baik, dan juga tidak ada pohon yang tidak baik yang menghasilkan buah yang baik. (44) Sebab setiap pohon dikenal pada buahnya. Karena dari semak duri orang tidak memetik buah ara dan dari duri-duri tidak memetik buah anggur.

${ }^{90}(45)$ Orang yang baik mengeluarkan barang yang baik dari perbendaharaan hatinya yang baik dan orang yang jahat mengeluarkan barang yang jahat dari perbendaharaannya yang jahat. Karena yang diucapkan mulutnya, meluap dari hatinya." memberikan teladan kepada umatnya bagaimana konsep tentang perdamaian itu dipraktekkan dalam kehidupan. Satu-satunya cerita yang menceritakan bahwa Yesus marah adalah ketika Yesus mengambil cambuk dari tali dan mengusir pedagang-pedagang dan penukar uang di halaman Bait Allah ${ }^{91}$. Tindakan ini tentu saja sama sekali tidak membahayakan siapapun kecuali nyawanya sendiri, karena semenjak peristiwa tersebut para pejabat Yahudi sepakat untuk menghukum mati Yesus. Masih banyak lagi cerita-cerita tentang Yesus dalam mengajarkan perdamaian dimana hal tersebut membuat umat kristiani terinspirasi untuk senantiasa membawa membawa misi perdamaian di muka bumi.

Damai dalam pandangan agama kristiani merujuk pada kata eirene dalam bahasa Yunani atau syallom di dalam bahasa Ibrani yang kemudian diterjemahkan menjadi damai sejahtera. Damai tidak hanya berarti bahwa tidak ada perang, pertikaian atau kekacauan, tetapi suasana hati dan lingkungan masyarakat di mana hubungan manusia dengan sesama, lingkungan dan diri sendiri tenang, bahagia dan terbuka kepada sang pemberi damai.

Upaya membangun perdamaian sebagaimana pesan bible ini juga menginspirasi gereja katolik, dimana dalam peribadatan dilengakpi dengan saling menyampaikan salam damai. Pesan damai dalam bible juga menginspirasikan pacem in terris dalam salah satu ensiklik ${ }^{92}$. Pacem in Terris berarti damai di bumi. Ensiklik ini ditulis oleh Paus Yohanes XXIII dan diterbitkan pada tanggal 11 April 1963 yang hingga saat ini masih diperingati dan masih cukup relevan. Didalam Pacem in Terris disebutkan bahwa perdamaian bertumpu pada empat tiang penyangga, yakni kebenaran, keadilan, cinta dan kemerdekaan.

Kebenaran merupakan tiang pertama, karena temasuk di dalamnya pengakuan bahwa manusia itu

${ }^{91}$ Yohanes $2: 13-25$

${ }^{92}$ Istilah ensilik secara etimologis berasal dari bahasa Yunani egkyklios, kyklos yang berarti edaran. Pada dasarnya itu adalah surat edaran. Sekarang ini istilah itu dipergunakan didalam kalangan gereja katolik untuk menunjuk pada surat-surat Paus yang disampaikan kepada umat katolik. 
bukan merupakan penentu dirinya sendiri melainkan bahwa dia dipanggil untuk memenuhi kehendak Tuhan, pencipta segalanya, yang merupakan Sang kebenaran mutlak. Dalam hubungan manusiawi, kebenaran itu mengandaikan ketulusan, yang merupakan syarat untuk saling percaya dan dialog menuju perdamaian.

Perdamaian tidak dapat terjadi tanpa keadilan, hormat kepada martabat dan hak perorangan. Tanpa keadilan baik dalam hubungan pribadi, sosial maupun internasional akan menyebabkan kekacauan dan kekacauan akan menyebabkan kekerasan di bumi. Keadilan juga harus dilengkapi dengan cinta. Dengan cinta, maka sesama manusia akan menjadi saudara, sehingga akan terjadi hubungan untuk saling berbagi baik dalam kesengsaraan maupun kegembiraan. Cinta juga akan membuat manusia untuk sanggup mengampuni dan memaafkan karena pengampunan adalah salah satu faktor yang penting dalam memulihkan perdamaian setelah pecah pertikaian.

Baik kebenaran, keadilan maupun cinta itu mengandaikan adalanya kemerdekaan sebagai salah satu sifat hakiki yang dimiliki dengan manusia. Kemerdekaan akan memungkinkan manusia untuk bertindak berdasarkan akalnya dan memikul tanggungjawab atas segala tindakannya sendiri, karena manusia secara pribadi akan bertanggung jawab dihadapan Tuhan atas segala tindakannya ${ }^{93}$.

Dari sini sangat terlihat bagaimana perdamaian yang tertulis dalam teks bible itu kemudian coba dikembangkan oleh umat kristiani (katolik) dalam Pacem Terris, sehingga apa diajarkan oleh Yesus di dalam bible dapat dilaksanaan oleh para jemaat.

\section{Ajaran Damai dan Masa Depan Indonesia}

Perdamaian tidak hanya bermakna damai dalam arti tidak dalam kondisi peperangan, tetapi perdamaian juga mencakup makna yang lebih luas, yakni suatu kondisi dimana sudah tidak ada lagi

${ }^{93}$ Muhaimin AG (ed.), Op. Cit, hlm 166-167 kekerasan struktural atau terciptanya keadilan sosial. Perdamaian dalam konsep ini meliputi semua aspek tentang masyarakat yang baik, seperti: terpenuhinya hak asasi yang bersifat universal, kesejahteraan ekonomi, keseimbangan ekologi dan nilai-nilai pokok lainnya. Berdasarkan konsep ini, perdamaian bukan hanya merupakan masalah pengendalian dan pengurangan tercapainya semua aspek tersebut, namun perdamaian merupakan konsep yang cukup luas dan pencapaiannya membutuhkan proses yang panjang. Dari sini dapat dilihat bahwa baik di dalam al-Qur'an maupun dalam bible, perdamaian juga mencakup makna yang luas ini. Disana terdapat konsep keadilan, kasih sayang, hubungan antar agama hingga ayat-ayat yang menjelaskan pada tataran praktis bagaimana cara mengakhiri konflik, pentingnya pemberian maaf dan lain sebagainya.

Perdamaian dalam bahasa al-Qur'an disebut salam dan dalam bahasa bible disebut syalom, merupakan inti ajaran dari kedua agama baik Islam maupun Kristen. kedua kitab tersebut sama-sama mengajarkan bagaimana membangun perdamaian di muka bumi ini, meski dalam prakteknya banyak sekali terjadi konflik yang menyebabkan peperangan dan munculnya banyak kekerasan atas nama agama. Karena meski di dalam al-Qur'an dan bible terdapat banyak ayat-ayat yang mengajarkan perdamaian tetapi disana juga terdapat ayat-ayat tentang peperangan yang seringkali dijadikan landasan untuk melakukan peperangan dan kekerasan. Didalam alQur'an misalnya ayat-ayat tentang jihad seringkali dimaknai sebagai ayat perang, sehingga perintah untuk berjihad ditafsirkan sama dengan perintah untuk berperang. Padahal jihad mempunyai makna yang sangat luas dan tidak hanya bisa dimaknai dengan perang. ${ }^{94}$ Disinilah sebenarnya yang menjadi

${ }^{94}$ Quraish Shihab misalnya memaknai jihad dalam konteks yang lebih luas, seperti jihad dalam rangka melawan hawa nafsu, melawan musuh serta melawan setan, baik yang dilakukan dengan cara membangun perdamaian dan keadilan, memberantas kebodohan, kemiskinan serta berbagai cara yang lain. Dari sini kemudian maka, sebenarnya konsep jihad menurut Quraish Shihab tidaklah bisa disamakan dengan perang, meski keduanya saling terkait dalam hal ini perang menjadi salah satu bagian dari jihad. Lihat M.Quraish Shihab, Tafsir Al-Misbab: Pesan, Kesan dan 
persoalan besar di kalangan umat baik Islam maupun Kristen. Persoalan penafsiran terhadap ayatayat yang terdapat di dalam al-Qur'an dan bible, sehingga memunculkan "persoalan" dalam tataran praktis di kalangan umatnya, padahal al-Qur'an dan bible sendiri justru malah memperingatkan umatnya untuk tidak saling membunuh dan berperang. Peperangan hanya diperbolehkan jika dalam kondisi untuk mempertahankan diri.

Disini sengaja penulis tidak berupaya untuk membuat komparasi diantara keduanya dan hanya sekedar memaparkan bagaimana sebenarnya konsep perdamaian itu dalam perspektif al-Qur'an dan Bible, karena pada dasarnya di dalam kedua kitab tersebut banyak sekali ayat-ayat yang terkait dengan perdamaian, sehingga dapat dikatakan bahwa kedua ajaran agama tersebut sama-sama mengajarkan dan mengajak umatnya untuk senantiasa membuat perdamaian di muka bumi. Sang pembawa damai (Muhammad dan Yesus) juga sama-sama memberikan teladan bagaimana perdamaian dapat dicapai meski keduanya samasama harus mengalami berbagai pengalaman pahit untuk mewujudkan itu.

Dalam konteks Indonesia, Konsep perdamaian yang berangkat dari kitab suci seperti yang telah disebutkan diatas tentulah sangat penting untuk kembali dikaji dan diaplikasikan oleh masyarakat Indonesia yang sedemikian plural. Kehidupan masyarakat Indonesia yang terdiri dari beragam suku, agama dan budaya dan telah berjalan harmonis selama ini tentu saja harus selalu dilestarikan. Apa yang terjadi jika konsep-konsep perdamaian tidak difahami dan dihayati oleh para pemeluk agama masig-masing. Tentu saja masyarakat Indonesia akan selalu berada didalam bayang-bayang konflik yang tidak berkesudahan. Dalam Islam misalnya, ayat-ayat yang berbicara tentang diizinkannya perang oleh Allah kepada kaum muslimin pada saat

Keserasian al-Qur'an, (Jakarta: Lentera Hati, 2004), vol 5, hlm 169-170. Lihat juga M. Quraish Shihab, Wawasan al-Qur'an: Tafsir Maudhu'i atas Pelbagai persoalan umat, (Bandung : Mizan, 1996), hlm 501 itu adalah karena penindasan yang dilakukan oleh kaum musyrikin yang tidak mau menerima pluralitas keagamaan. Dalam konteks ini kaum musyrikin menolak hak untuk beragama kaum muslimin sehingga kaum muslimin berada dalam kondisi yang tertindas dan tidak bebas menjalankan ibadahanya. Dari sini, sebagaimana yang dijelaskan oleh Quraish Shihab, izin untuk berperang melawan kaum kafir ini bukan dikarenakan oleh kekufuran mereka atau keengganan mereka masuk Islam tetapi lebih karena penganiayaan yang telah dilakukan. Disini terlihat bagaimana pesan utama dari ayat diizinkannya perang bagi kaum muslimin adalah bertujuan untuk menghapus penindasan dan menegakkan kebebasan beragama serta perdamaian. ${ }^{95}$ Karena pada dasarnya Islam memang mengajarkan untuk tidak memaksakan seseorang dalam beragama dan Islam menjamin kebebasan itu. ${ }^{96}$

Upaya perdamaian hendaknya memang dilakukan oleh berbagai pihak, baik agamawan, cendekiawan, negarawan hingga masyarakat secara luas. Disini agamawan mempunyai peran yang cukup penting dan menjadi ujung tombak dari terselesaikannya konflik atas nama agama. Hal ini karena konflik-konflik atas nama agama menjadi isu yang cukup rawan dalam masyarakat. Untuk itu penting kiranya adanya berbagai upaya seperti dialog antar agama sehingga perdamaian yang diimpikan dapat betul-betul terwujud.

\section{Kesimpulan}

Dari uraian diatas, setidaknya kita bisa memahami bagaimana konsep perdamaian ini merupakan konsep yang cukup luas dan pencapaiannya membutuhkan proses yang panjang, dimana konsep perdamaian ini bisa dicari akarnya

${ }^{95}$ Sahiron Syamsuddin, "Pesan Utama Ayat Perang: Tafsir atas Surat al-Hajj Ayat 39-40", dalam majalah Bangkit; Menebar Rahmah Ablussunnah Wal-jamaah, edisi November 2012..hlm 6

${ }^{96}$ Terkait dengan kebebasan ajaran Islam. Quraish Shihab menjabarkannya dalam beberapa hal, yakni (1) Kebebasan nurani manusia, (2) Kebebasan beragama, (3) Kebebasan berpikir, (4) Kebebasan Berbicara,(5) Kebebasan dari Rasa Takut, (6) Kebebasan dari Kebutuhan. Lihat M. Quraish Shihab, Secercab Cahaya Ilabi; Hidup Bersama Al-Qur'an, (Bandung: Mizan, 2000), hlm 331 
dari ajaran agama manapun. Karenanya memahami pentingnya perdamaian ini, seharusnya kesadaran akan pluralitas agama dengan menghargai keberadaan agama lain menjadi hal yang peting dalam konteks keberagamaan di Indonesia yang terdiri dari beragam agama. Kesadaran adanya pluralitas agama ini, bukan berarti tidak dan atau kurang meyakini kebenaran agama yang dianut, tetapi lebih pada tuntutan untuk menghargai dan menghormati agama dan kepercayaan lain yang konteks kebangsaan, yakni sama sama terlahir dari rahim sebangsa dan setanah air.

\section{Referensi}

Andreski, Stabislav, Max Weber: Kapitalisme, Birokrasi dan Agama, terj. Hartono H, Yogyakarta: Tiara Wacana, 1996.

Coward, Harold and Gordon S Smith (ed.), Religion and Peacebuilding, (USA : State University of NewYork, 2004), hlm 130-131.

Muhaimin AG (ed.), Damai di dunia Damai untuk Semua Perspektif berbagai Agama, (Jakarta :
Proyek Peningkatan Pengkajian Hidup Umat Beragama, Badan Litbang Agama dan Diklat Keagamaan, Departemen Agama RI.

Shihab, M.Quraish, Tafsir Al-Misbab: Pesan, Kesan dan Keserasian al-Qur'an, Jakarta: Lentera Hati, 2004), vol 5.

\section{Wawasan al-Qur'an:}

Tafsir Maudhu'i atas Pelbagai persoalan umat, Bandung : Mizan, 1996.

Secercab Cahaya Ilabi;

Hidup Bersama Al-Qur'an, Bandung: Mizan, 2000.

Suherlan, Ian, Menegakkan Perdamaian dan Keadilan, Buletin No. 185, www.cmm.or.id/ cmm-ind_more.

Syamsuddin, Sahiron, "Pesan Utama Ayat Perang: Tafsir atas Surat al-Hajj Ayat 39-40", dalam majalah Bangkit; Menebar Rahmah Ablussunnah Wal-jamaah, edisi November 2012. 